\title{
The resilience of high school students, analysis of compensatory measures, and preferred strategies for coping with adverse situations
}

\author{
Lucie Nečasová
}

\section{Contact}

Tomas Bata University in Zlín

Faculty of Humanities

Štefánikova 5670

76001 Zlín

I_hornakova@utb.cz

Correspondence:

I_hornakova@utb.cz

Copyright (C) 2021 by the author and publisher, TBU in Zlín.

This work is licensed under the Creative Commons Attribution International License (CC BY).

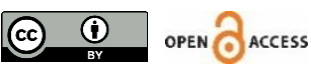

\begin{abstract}
The study presents the results of measuring the resilience of high school students. The main goal is to find whether there is a link between the resilience of students and preferred coping strategies. Quantitative research was subsequently conducted with students in the 2 nd and 3 rd years of secondary schools. The research included a questionnaire survey in which students were presented with two questionnaires. The first questionnaire was self-designed and aimed to assess the level of resilience; the second standardized questionnaire focused on the preferred choice of coping strategies. Responses were received from a total of 516 respondents. The data were evaluated using the tools of descriptive statistics. The results showed that pupils' resilience is generally at a good level. In addition, five key factors improving and lowering resilience were identified. Furthermore, five preferred strategies and five strategies that students prefer to avoid when dealing with problem situations were identified. At the same time, a direct correlation between the effort to take an active approach to solve problems and the degree of resilience was observed; this is considered to be the main outcome of the study.
\end{abstract}

Keywords: pupil, resilience, coping strategy, problem situation, high school

\section{Resilience žáků středních škol, analýza vyrovnávacích opatření a preferované strategie zvládání nepř́znivých situací}

\begin{abstract}
Abstrakt: Studie předkládá výsledky měření resilience žáků středních škol. Hlavním cílem je zjistit, zda existuje souvislost mezi mírou resilience žáků a volbou preferovaných zvládacích strategií. $V$ rámci studie byl realizován kvantitativní výzkum s žáky druhých a třetích ročníků středních škol. Výzkum spočíval $v$ dotazníkovém šetření, kdy byly žákům předloženy dva dotazníky. Cílem prvního dotazníku, který byl vlastní konstrukce, bylo stanovit míru resilience, druhý, standardizovaný dotazník se zaměřil na preferovanou volbu zvládacích strategií. Byly získány odpovědi od celkem 516 respondentů. K vyhodnocení dat byly použity nátroje popisné statistiky. Výsledky ukázaly, že resilience žáků je celkově na poměrně dobré úrovni. Dále bylo vytipováno
\end{abstract}


pět zásadních faktorů zvyšujících a snižujících resilienci a vyplynulo pět preferovaných strategií a pět strategií, kterým se žáci spíše vyhýbají při řešení nepříznivých situací. Současně byla pozorována prrímá závislost mezi snahou aktivně přistupovat $\mathrm{k}$ řešení problémů a mírou resilience. Toto zjištění je jedním z hlavních výstupů této studie.

Klíčová slova: žák, resilience, zvládací strategie, nepříznivá situace, střední škola

\section{Introduction}

School is a significant source of resilience in the life of an adolescent, and the daily operation of a school for several hours can significantly contribute to a student's feeling of success or failure (Šolcová, 2009). It is evident that attention is being paid to the topic of resilience in education; for example, Ungar, Russell, and Connelly (2014) point to the fact that there is evidence that schools have great potential to positively influence children's biopsychosocial growth and development, and that the school can have a significant impact on the future development and psychological resilience of students. Adolescents dealing with everyday life have various worries and problems that most often concern school, relationships with peers, and self-image. These perceived concerns associated with education can have an impact not only on their overall level of resilience but also on their satisfaction at school (Macek, 2003).

The stressful situations that students deal with in connection with school include, for example, completing a task that is beyond their capabilities, coping with being unpopular students, surviving a fight, and being able to get along with a teacher who is biased towards them (Neuman, 2007). The time in which children and adolescents are living places great demands on their mental resilience. During their life, each person encounters various stressful situations that can harm their healthy development. Under the influence of this stress, he reacts to everyday situations differently or unexpectedly, and even his personality strengths cannot always prevent negative manifestations (Barnová, 2009). Adults often do not even realize how difficult a period of life adolescence can be. Some can cope better with this pressure than others. We need to think about how a student can deal with a stressful situation, how resilient that individual is, and whether they have a defensive reaction or a coping reaction.

Resilience generally refers to the psychosocial processes of coping with life disadvantages in such a way that all the development and functioning of the individual remains normal. Specifically, resilience is defined as an individual's ability to orient themselves in their own psychological, socio-cultural, and physical resources, which maintain their well-being and ability to negotiate individually, and collectively to provide these resources in a meaningful way (Ungar et al., 2008).

To understand how some children and adolescents overcome difficulties and experience success despite apparent risk factors, researchers such as Benard (1991), Taylor and Thomas (2001), and Ungar et al. (2014) focus on understanding concepts of resilience and identifying protective factors and processes that improve or dampen an individual's response to challenging life situations. Resilience can be found both in individuals and in relationships between people, increasing students' life chances and success at school (McMahon, 2007).

This study examines the degree of resilience in high school students and the coping strategies that students choose for coping with adverse school situations in a psychosocial context. Given the stated research goals and the work's primary goal, which is focused on identifying the relationship between strategies for managing adverse situations and the degree of resilience of high school students, a quantitative research concept was implemented through a questionnaire survey. 


\section{Problems with the coping strategies of high school students}

Challenging life situations are considered one of the most basic factors that shape a student's personality. Certain levels of stress can lead students to better performance and be their driving force. However, if stress is not addressed effectively due to insufficient capacity to manage stress, negative consequences can occur, for both the student and the institution (Reddy, Menon, \& Thattil, 2018). The consequences of academic stress can also cause depression, anxiety, behavioural problems, and irritability in adolescents (Deb, Strodl, \& Sun, 2015). Adolescence is characterized as a turbulent time in which very high demands are placed on adolescents in all respects (Vašutová \& Panáček, 2013). With increased demands during adolescence, there is also a change in the attitude towards the pupil's role. This manifests itself primarily in changing attitudes towards the teacher and rejection of his formal superiority, which manifests itself in symbolic confrontation, the pursuit of equal discussion, and negativism (Vágnerová, 2001). In terms of stress, workload, and adaptation, the school has a unique position, as school institutions have significant power to contribute to adaptation skills (Šolcová, 2009). A stressful school situation is a current or potential situation that a pupil considers unpleasant or demanding, or describes as a situation that threatens or is dangerous for them (Čáp \& Mareš, 2007). The most important sources of stressful situations for pupils at school are school performance (fear of tests, papers, and marks), bullying, and fear of classmates.

The main coping strategies are usually described as active coping, seeking social support, trying to change one's personality, and the ability to cope with stress (Poledňová, Stránská, Vízdalová, \& Zobačová, 2003). Stressful situations can be assessed both by the student himself and by his parents, friends, and teachers. The key, in this case, is how the student himself sees the specific stressful situation, because his perception also reflects his reactions. It is also essential to keep in mind that the assessment from the student's point of view may differ significantly from others' assessments. In the literature, there are usually two types of assessment in managing the workload of students: a primary type and a secondary type (Čáp \& Mareš, 2007).

The factors that make it easier for individuals to manage the workload at school can be divided into three categories. The first of these categories represents individual internal sources of coping - pupil optimism (Čáp \& Mareš, 2007), social competence (Masten, Best, \& Garmezy, 1990) and pupil selfconfidence (Leary, Tambour, Terdal, \& Downs, 1995). The second category includes interpersonal factors - safe background ("Building resilience in schools," 2016), family (Newman \& Blackburn, 2002), caring and supportive relationships, and friendship (Benard, 1991). The third category includes factors of the school and its environment - teachers and school staff (Masten \& Coatsworth, 1998), school culture and climate (Weare \& Nind, 2011), and education (Ungar et al., 2014).

Risk factors include temperament characteristics such as neuroticism, peculiarities in thinking, developmental delays, disability, serious illness, learning and behavioural disorders or long-term exhaustion, adverse family influences, adverse influences from the community in which the pupil lives, and cultural and ethnic influences (Čáp \& Mareš, 2007). Adverse school influences associated with education and academic success include, in particular, inappropriate ways of testing and evaluating pupils, negative attitudes of teachers towards pupils, conflicts between teacher and pupil, adverse school/classroom climate, competition with classmates, social isolation of pupils in class, poor grades, long-term school failure, and the absence of informal or formal social support for school problems (Čáp \& Mareš, 2007). After defining all the above factors, we can say that the teacher should be a source of social support for his students. An analysis of the concept of social support distinguishes its different types: support that is either offered, sought after, provided, acquired, or perceived. We can also mention three essential functions that social support fulfils: damping effect, direct impact, and indirect effect.

The peculiarities of the teacher, which can strengthen or complicate the teacher's role as a social support for the student, include primarily personality peculiarities, the teacher's willingness to help, the way of responding to a student's request for help, the teacher's expectations related to the 
difficulty of the curriculum for students, the teacher's competence to help students, the teacher's mutual relations with pupils, and the teacher's current mood (Mareš, 2003).

Strategies for developing resilience in the classroom (Wedlichová, 2010) are strategies for successfully overcoming obstacles and stressful situations (Bickart \& Wolin, 1997), which includes participation of students in setting goals and evaluating their own work, cooperation in achieving educational goals with others, involvement of students in solving problems in the classroom together, availability of choices, enabling students to feel part of a larger group, and promoting an active role in setting the rules of classroom life. Coping strategies for increasing the level of resilience in school includes mainly perceptive listening, speaking the language of another, avoiding negative language forms, and restructuring (Wedlichová, 2010).

It follows from the above that the issue of compensatory measures and strategies for dealing with adverse situations, which ultimately implies the resilience of high school students, is very complex. At the same time, several different aspects and perspectives need to be considered. However, it is indisputable that this is one of the critical areas of social pedagogy. This is evidenced by the fact that more and more studies address the impact of the school environment and climate. So far, however, research has not addressed the choice of optimal coping strategies for increasing student resilience. This work therefore aims, based on quantitative research, to understand the correlation between the strategy of coping with adverse situations and the degree of resilience of students.

\section{Methods}

\subsection{The aim of the study}

Based on limited research carried out in the Czech Republic, this study aimed to discover the presence of a connection between adverse management strategies and the level of resilience of secondary school pupils. The following research questions, arising from this objective, were further set forth:

RQ1: What is the resilience rate of high school students based on a subjective assessment of resilience?

RQ2: What factors positively impact pupils' resilience in high schools based on a subjective assessment of resilience?

RQ3: What factors harm pupils' resilience in high schools based on a subjective assessment of resilience?

RQ4: What coping strategies do high school students employ in dealing with adverse situations at school?

RQ5: What coping strategies do high school students prefer?

RQ6: What coping strategies do high school students avoid?

RQ7: What is the connection between the choice of management strategies and degree of resilience of high school students?

\subsection{Participants and procedure}

The primary research group consists of 2 nd- and 3rd-year high school students aged 16-18 in the Czech Republic. This age range is optimal for the selected standardized questionnaires. The Statistical Yearbooks of Education of the Ministry of Education, Youth and Sports („Statistické ročenky školství,“ 2020) state that in the Czech Republic, 1,284 institutions providing secondary education were registered in the 2019/2020 school year. In the primary research, we included students who are engaged in secondary education, secondary education with an apprenticeship certificate, and secondary education with a school-leaving examination. Specifically, these are grammar schools and secondary vocational schools. 
All the levels of secondary education mentioned above meet our primary research group's criteria, as all students from the research group are in either the 2 nd or 3 rd year. 408,086 pupils are engaged in a full-time form of education. In the 2019/2020 school year, the 2 nd year of secondary schools was attended by a total of 101,008 full-time pupils, and 91,905 pupils participated in the 3rd year of secondary schools full-time. In total, there are 192,913 pupils. These students form our primary set.

The sample consists of pupils who were selected based on a random multi-stage selection. According to Gavora (2000), random selection is the best choice in probability theory, as each student in the research has the same chance of being selected. The objectivity of the selection is therefore guaranteed. For random selection, we chose the method of drawing; in the first stage, the individual regions were drawn. Lotteries were drawn from all 14 regions of the Czech Republic.

As can be seen below in Table 1, three regions were drawn. Primary attention was paid to the number of respondents. Based on an overview of schools in the individual areas, it was assumed that selecting schools from the three drawn regions, namely the Moravian-Silesian, South Moravian and Olomouc regions, would provide a sufficient number of respondents. The next stage was the drawing of secondary schools in these regions. We obtained a list of schools in the particular areas from the („Rejstřík škol,“ 2020). Five schools were selected from each of the three regions by drawing lots, for a total of 15 schools. A total of about 2,500 pupils were contacted; the number of returned questionnaires was 516 , with a response rate of $21 \%$.

Table 1

Number of schools and pupils in drawn regions

\begin{tabular}{lcc}
\hline Region & Secondary school $(n)$ & Pupils $(n)$ \\
\hline South-Moravian region & 123 & 44,890 \\
Olomouc region & 94 & 26,053 \\
Moravian-Silesian region & 136 & 45,827 \\
Total & 353 & 116,770 \\
\hline
\end{tabular}

\subsection{Research methods}

An approach based on a questionnaire survey was chosen for the quantitative research. A Resilience Doughnut Model questionnaire (Worsley, 2006) was used to determine the overall rate of resilience of high school students, as well as the factors that affected resilience the most and the least. We define seven areas of resilience that have a positive and negative impact on adolescents. The questionnaire was self-designed, and it was easily modified to be applicable in the Czech environment - some questions that sounded very similar were merged. It focuses on determining the overall rate of resilience and contains seven areas of resilience.

Our modified questionnaire therefore contains 35 items and is divided according to seven factors: parents; interest/skills; family and personal identity; education; peers; community; and financial/financial security. Each part includes five items. Only one answer is possible using a 4-point Likert scale ranging from 1 (definitely yes) to 4 (definitely no). Unless otherwise stated, the lower score represents a higher resilience rate. Furthermore, one of the items was reversible and therefore was recorded before the statistical analysis.

To measure and analyse strategies for coping with adverse situations at school, the CTK questionnaire (Kohoutek, Mareš, \& Ježek, 2008) was used. The CTK questionnaire monitors the structure of the psychosocial workload and preferred coping strategies. The questionnaire contains 35 strategies that students use to cope with disadvantaged situations. According to the authors, it is possible to work with the following seven domains: active search solution; deviation/escape from the problem; seeking social support; confident, functional solutions; isolation; succumbing to the problem; passive reactions to the problem (Kohoutek et al., 2008). Pupils assessed individual statements on a 4-point scale ranging from 0 (not valid) to 3 (valid). 


\subsection{Data analysis}

To find the answers to research questions, descriptive statistics (i.e. mean and standard deviation) were used. One of the research questions (RQ7) was relational and found the connection between management strategies and the degree of resilience of secondary school pupils. The hypothesis expected a link between the choice of coping strategies and the degree of resilience of secondary school pupils. Pearson's correlation coefficient was used, with assumptions checked. In the case of our hypothesis, we expected a linear relationship between the two variables. Because we could not claim that one variable directly affected the other variable's values, we used correlation analysis to evaluate the relationship. Dependent and independent variables were determined from this hypothesis. Minitab 19 software was selected for statistical data analysis.

\section{Results}

The summary analysis of the data shows that the total resilience of high school students is $M=2.00$ $(S D=1.00)$. The degree of resilience could be considered neutral if the average value was based on $M$ $=2.50$. Based on the data, it can be stated that the respondents who participated in this research show an increased rate of resilience.

Based on further statistical analysis of the data and a comparison of results from research questions focused on the school resilience questionnaire, the five most important factors that positively impact the resilience of high school students were identified. Table 2 shows the mean values of five of the most positive factors regarding the resilience of high school students.

Table 2

Factors having a positive impact on the resilience of high school students

\begin{tabular}{lc}
\hline Factor & M (SD) \\
\hline Parents' influence - my parents appreciate me & $1.46(0.71)$ \\
Parents' influence - my parents are responsible & $1.55(0.73)$ \\
Influence of interests/skills & $1.60(0.81)$ \\
Influence of peers & $1.61(0.82)$ \\
Influence of education & $1.67(0.75)$ \\
\hline
\end{tabular}

Note. $\mathrm{M}=$ mean; $\mathrm{SD}=$ standard deviation.

Table 3 identifies the five key factors that were shown by the school resilience questionnaire to harm the resilience of secondary school pupils.

Table 3

Factors having a negative impact on the resilience of high school students

\begin{tabular}{ll}
\hline Factor & $M(S D)$ \\
\hline Community influence - I am religious & $3.32(0.94)$ \\
Community influence - I am a member of sport club & $3.01(1.30)$ \\
Influence of interests/skills - I am a member of supporting organization & $2.58(1.22)$ \\
Influence of interests/skills - I am self confident & $2.57(0.94)$ \\
Influence of education & $2.40(0.95)$ \\
\hline
\end{tabular}

Note. $\mathrm{M}=$ mean; $\mathrm{SD}=$ standard deviation.

Focused on the CTK questionnaire, Table 4 shows the five coping strategies that high school students most often choose in response to a problem. Strategies are ranked in descending order, from the highest score achieved to the lowest. 
Table 4

The most popular coping strategies

\begin{tabular}{lc}
\hline Coping strategies & $M(S D)$ \\
\hline Management strategies involving active solutions & $2.24(0.85)$ \\
Coping strategies involving a passive response to a problem & $2.16(0.98)$ \\
Management strategies involving insulation & $2.12(0.93)$ \\
Coping strategies involving seeking social support & $2.02(0.87)$ \\
Coping strategies involving an active search for solutions & $2.06(0.87)$ \\
\hline
\end{tabular}

Note. $\mathrm{M}=$ mean; $\mathrm{SD}=$ standard deviation.

Table 5 below shows data from the CTK questionnaire. Five coping strategies have been identified that secondary school students choose the least in response to a problem. Strategies are listed in ascending order, from lowest score to highest.

Table 5

Avoiding coping strategies

\begin{tabular}{lc}
\hline Coping strategies & $M(S D)$ \\
\hline Coping strategies involving a passive response to a problem & $0.68(0.91)$ \\
Management strategies involving insulation & $1.14(1.00)$ \\
Coping strategies involving seeking social support & $1.29(0.95)$ \\
Coping strategies involving confident, active solutions & $1.30(0.95)$ \\
Coping strategies involving succumbing to a problem & $1.36(0.97)$ \\
\hline
\end{tabular}

Note. $\mathrm{M}=$ mean; $\mathrm{SD}=$ standard deviation.

The degree of correlation between the two questionnaires based upon the average values was assessed to determine how and whether the choice of coping strategies and the degree of resilience of secondary school pupils are related. Based on the Pearson correlation coefficient results, it turned out that there is a direct ratio between the variables. Based on a direct correlation, we find that the higher the resilience rate of high school students, the greater the tendency and ability to solve problems. In cases where an individual, regardless of the chosen strategy, tends to resolve an unfavourable situation at school, they show a higher degree of resilience as a result. This confirmed our working hypothesis, which we set at the beginning.

From the performed statistical analysis of the questionnaire "The Resilience Donut" and the questionnaire "CTK", we can assert a connection between the choice of coping strategies of high school students $(M=1.66, S D=0.40)$ and the degree of resilience $(M=2.00, S D=0.36)$. The correlation coefficient reached the value of $r=.160(p<.05)$, and we can say that it is a direct correlation. Based on a direct correlation, we find that the higher the resilience rate of high school students, the greater the tendency and ability to solve problems. If an individual tends to deal with an unfavourable situation at school, regardless of the chosen strategy, he/she shows a higher degree of resilience as a result. Conversely, individuals who tend to prefer "rather not" are less resilient.

\section{Discussion}

In the first, second and third partial research questions, we found the overall degree of resilience of high school students and discovered what has a positive influence and, conversely, a negative impact on their resilience. The seven areas of resilience tested were addressed in The Resilience Donut Model (Worsley, 2006). If the resulting value is less than 2.50, the result indicates that students are resilient. On the contrary, the further the result deviates from the value of 2.50, the lower the degree of resilience the pupils show. Based on the results, we can state that of the seven tested areas of resilience examined by the questionnaire, the Parental Factor area is the best. This factor placed first 
and second among respondents in the ranking of factors that positively impact pupils' resilience. Among respondents, it is therefore considered the most important in terms of their degree of resilience. In terms of resilience, the literature repeatedly mentions that children cannot build their psychological resilience without love, support, and positive relationships. All of this is based primarily on the family or primary care setting (Newman \& Blackburn, 2002). Benard (1991) further states that caring and supportive relationships within a safe environment with a trusted adult are essential for the child's development and provide a basic form of resilience, reflected in school success.

The third- and fourth-best-rated areas fall into the Interest/Skills category. As for the previous factor, this area also ranked twice in the ranking of positive influences. This category includes questions that point to increased self-confidence. This corresponds to the literature, where this area is emphasized as an essential factor in resilience. Research conducted by Leary et al. (1995) puts the student's selfconfidence in an exciting context within Maslow's hierarchy of needs, mentioning the maintenance of self-worth as the primary determinant of self-sufficiency, resilience, and mental health. Buckner, Mezzacappa, and Beardslee (2003), in turn, show that resilient children and adolescents with higher intrinsic value tend to be less involved in risky behaviour compared to those who are less resilient and therefore have less self-confidence.

The Education factor also performed relatively well among the respondents. Respondents perceive involvement in various activities and awareness about what happens at school as being the most important things in this area. This area also focused on the relationship between teachers and students and the school environment. The fact that it is in a higher position in the evaluation of pupils means that it is important for pupils to know that they feel good at school. We can confront this view with research from Roorda, Koomen, Split, and Oort (2011), which shows that positive teacher-pupil relationships are associated with increased cognitive, behavioural, and emotional involvement in learning, as well as improved academic performance, while negative teacher-student relationships are associated with worse involvement and failures. School culture and climate also play an important role in resilience. Weare and Nind (2011) found that schools can build and develop their positive atmosphere by creating an intimate space between teachers and students where they can naturally talk about their emotions and mental health issues. With this approach, they contribute to a pupil's sense of belonging and connection with the school, and they improve the pupil's psychological resilience.

The worst results were achieved by the Community factor, which included the issue of both faith and the use of support services, as well as interest in organizations within the close community of people in which the pupils live. The area also included the proximity of a confidential person. This area occupied the two highest positions in the evaluation of adverse effects on pupils' resilience. Pupils in this area turned out to have the lowest resilience rate in the overall assessment. Here, it is necessary to consider whether it is a risk factor if the students answered that they are not believers and that faith does not help them overcome difficulties. The question of personal faith is so intimate and subjective that it cannot be generalized enough to state whether it is a risk or a supporting factor for students. Besides, we live in a time when the number of believers is generally declining, and it is not so common to find faith in young people.

As for the second-worst area, which also falls under the community factor, the question is whether it is caused by the adverse influence of the community in which the student lives (socially or in the area of health risk), or whether there are cultural and ethnic influences - experience with discrimination, isolation or rejection (Čáp \& Mareš, 2007). However, it was confirmed that a safe background provides protection for both the individual, family, and community. The third- and fourth-worst results were achieved by the Interest/Skills area. Students who do not attend any hobby group where their abilities are supported and developed have lower resilience. However, this area also includes whether students master at least one skill and whether they do not give up after initial failure. According to Ježek (2012), adolescents consider it essential when adults force them to perform better and support them in their 
interests, abilities, and skills, whether in-school or out-of-school. Therefore, if adolescents have no interests and skills, their resilience cannot increase.

It is also worth mentioning the fourth-worst-rated area, which is related to the skill factor, where a surprisingly large proportion of students answered that they do not have high self-confidence. Here we find a split between positive and negative influences on resilience, because it was in the positive effects that the Interest/Skills factor was rated relatively high. As the last-worst-rated factor, we will mention the Education factor, which indicates that pupils are not sufficiently involved in school activities and are not interested in what is happening at school. Sacker and Schoon (2007) suggest that a school can promote resilience by integrating psychological resilience-building into the curriculum of non-academic subjects. This could be pupils' creative achievements, the exhibition of works of art and other forms of art by pupils, or the involvement of pupils in school sports events as players or spectators.

Despite the negative results discussed in the last paragraph, it can be said that pupils' resilience is at a reasonable level in the overall context. Pupils show an increased level of resilience, better involvement in school activities and life, and higher self-confidence, which can contribute to further improvement. Based on an analysis of the second CTK questionnaire data, we can state that of the seven tested areas, the highest average score was obtained in the case of the Active Solution strategy. Pupils said they were thinking about how to solve the problem. Therefore they show a proactive approach to problemsolving. According to Neuman (2007), a student can perceive stress or stressful situations in two ways - either as an opportunity and a challenge or as a threat. If they consider them to be a threat, they withdraw and do not show the will to handle the problem. Thus, our respondents perceive the problems more as challenges, which also indicates good mental resilience. In the same area, we could observe another preferred strategy: the students try to figure out where they made a mistake. Neuman (2007) points out that the state in which students approach a problem actively evokes positive emotional states in them, which further motivates them and teaches them to apply their procedures.

The lowest score by far, and thus the least preferred strategy, was observed in the area of Passive Response to a Problem. Talking about a problem with a teacher had the smallest average value in the given category. It is somewhat astonishing that students avoid this strategy. This may be because the student perceives the teacher as an authority but does not have sufficient trust. Simultaneously, the student should realize that the teacher has the experience and can help very quickly and effectively. At this point, it should be emphasized that it would be appropriate for this item to work better, as the fact that a pupil is looking for a teacher indicates good relationships. The teacher's personality plays an important role in this case. A good teacher-student relationship increases student performance, promotes self-confidence, and significantly reduces unwanted behaviour (Cernkovich \& Giordano, 1992). However, the area of Passive Reaction also appeared among the most preferred strategies, where students stated that they imagined how good it would be if the problem did not exist. The idea is probably tempting for pupils but overlooked, and long-term unresolved issues can have several negative consequences for individuals and significantly reduce their resilience (Paulík, 2010).

Isolation was chosen as the second-worst strategy, where students fear that if they confide in someone, it would hurt them. It is interesting to relate this fact to the research of Gecková, Pudelský, and Tuinstra (2000), who pointed to the finding that isolation is almost non-existent in adolescents. However, it is necessary to consider the personal setting of each individual and the fact that even adolescents may feel closed in. It is also interesting to compare this finding with the third-leastpreferred strategy of Finding Social Support, where students stated that they are not looking for someone to help them with problems. The literature says that dealing with stressful situations in this form is relatively common. Seeking social support, whether in a teacher, peer or family member, is perceived as an essential factor in a safe background that provides an essential form of resilience (Benard, 1991). However, this statement was not confirmed in our research. By the way, it is also interesting that this area was also among the most preferred ways of coping when the interviewees 
stated that they were looking for some distraction or entertainment that would retune them and shift their thinking in a different direction.

The fourth-least-preferred strategy is the area of Self-Confident Active Solutions, where respondents stated that they hide their feelings and do not openly express them. We explain this finding by saying that students do not want to show that they do not know how to deal with a problem at a certain stage. They do not solve the problem, they mask it, and they pretend that the problem does not seem to exist. Directly related to this is the strategy of succumbing to the issue, where students try to control and act sensibly but often fail. Thus, students probably try to solve the problem with a calm head; however, students will succumb to it due to stress and cannot resolve the issue rationally if the problem goes into a difficult phase.

\section{Conclusion}

This study looked at the resilience of high school students and their preferred strategies for dealing with adverse situations. We focused on an analysis of compensatory measures. We mapped the supportive and risky areas for pupil resilience and identified the five most- and least-preferred strategies for dealing with adverse situations. In this study, we worked with the hypothesis that coping strategies and the degree of resilience of high school students are related.

This study aimed to find the overall rate of pupils' resilience in high school and what factors most and least affect pupils' resilience. We also focused on and analysed strategies for coping with adverse situations at school. Based on the main research goal, seven sub-goals were set, from which research questions subsequently arose. We chose a quantitative type of research to answer them and used a questionnaire survey method to collect data. More precisely, these were two questionnaires. The first focused on resilience and presented seven areas where psychosocial resilience skills can be developed. The second questionnaire dealt with strategies for managing adverse situations.

The main finding is that there is a connection between the choice of coping strategies and the degree of resilience of secondary school pupils, and it was possible to observe a direct correlation.

To summarize the main findings it can be stated that the respondents who participated in this research generally show an increased rate of resilience. The area that has the most positive impact on strengthening pupils' resilience is considered to be the Parental Influence factor, namely that pupils have parents who respect them and are happy to have them. On the contrary, we consider the Community Influence factor to be the most negative area concerning pupil resilience. The data analysis results further showed that, in general, we could state that students tend to resolve the problems and unfavourable situations they face. Pupils choose Active Solution as the most preferred coping strategy, namely, thinking about how a problem could be solved. Pupils choose the Passive Response to a Problem area, namely a conversation about the teacher's problem, as the least preferred coping strategy. Furthermore, we found that the higher the resilience rate of high school students, the greater the tendency and ability to solve problems.

\section{Declaration of conflicting interests}

No potential conflict of interest is reported by the authors.

\section{References}

Barnová, S. (2009). Rozvoj reziliencie v škole. Reziliencia a nové prístupy k výchove a vzdelávaniu. Bratislava: Comenius University in Bratislava. 
Benard, B. (1991). Fostering resiliency in kids: Protective factors in the school, community, and family. Portland: Western Regional Center for Drug-Free Schools and Communities, Northwest Regional Educational Laboratory.

Bickart, T. S., \& Wolin, S. P. (1997). Practicing resilience in the elementary classroom. Principal, 77(2), 21-22.

Buckner, J. C., Mezzacappa, E., \& Beardslee, W. (2003). Characteristics of resilient youths living in poverty: the role of self-regulatory processes. Developmental Psychopathology, 15(1), 139-162. https://doi.org/10.1017/S0954579403000087

Building resilience in schools: An evidenced-based review of the Kent HeadStart Programme Draft 'Resilience Toolkit' (2016). Data @ Kelsi. Retrieved from https://www.kelsi.org.uk/_data/assets/pdf_file/0016/61720/KCC-REPORT-FINAL-Resiliencetoolkit.pdf

Čáp, J., \& Mareš J. (2007). Psychologie pro učitele. Praha: Portál.

Cernkovich, S. A., \& Giordano, P. C. (1992). School bonding, race, and delinquency. Criminology, 30(2), 157-291.

Deb, S., Strodl, E., \& Sun, J. (2015). Academic stress, parental pressure, anxiety, and mental health among Indian high school students. International Journal of Psychology and Behavioral Sciences, 5(1), 26-34. https://doi.org/10.5923/j.ijpbs.20150501.04

Gavora, P. (2000). Úvod do pedagogického výzkumu. Brno: Paido.

Gecková, A., Pudelský, M., \& Tuinstra, J. (2000). Kontakty s rovesníkmi, sociálna siet́ a sociálna podpora z pohĺadu adolescentov. Psychológia a patopsychológia diet́ata, 35(2), 121-136.

Ježek, S. (2012). Vztahy s dospělými mimo rodinu. In P. Macek, \& L. Lacinová (Eds.), Vztahy v dospívání (pp. 81-91). Brno: Barrister \& Principal.

Kohoutek, T., Mareš J., \& Ježek, S. (2008). Coping in adolescence. In S. Ježek, \& L. Lacinová (Eds.), Fifteen-year-olds in Brno: A slice of longitudinal self-reports (pp. 55-64). Brno: Masaryk University.

Leary, M. R., Tambor, E. S., Terdal, S. K., \& Downs D. L. (1995). Self-esteem as an interpersonal monitor: The sociometer hypothesis. Journal of Personality and Social Psychology, 68(3), 518-530. https://doi.org/10.1037/0022-3514.68.3.518

Macek, P. (2003). Adolescence. Praha: Portál.

Mareš, J. (2003). Učitel jako zdroj sociální opory pro žáky a studenty. Studia Paedagogica, 51(8), 4154. Retrieved from https://www.phil.muni.cz/journals/index.php/studiapaedagogica/article/view/382

Masten, A. S., \& Coatsworth, J. D. (1998). The development of competence in favorable and unfavorable environments: Lessons from research on successful children. American Psychologist, 53(2), 205-220. https://doi.org/10.1037//0003-066x.53.2.205

Masten, A. S., Best, K. M., \& Garmezy, N. (1990). Resilience and development: Contribution from the study of children who overcome adversity. Development and Psychopathology, 2(4), 425-444.

McMahon, B. J. (2007). Resilience factors and processes: No longer at risk. The Alberta Journal of Educational Research, 53(2), 127-142.

Neuman, J. (2007). Řešíme problémy a prijímáme výzvy: tematický okruh osobnostnía sociální výchovy Řešeni problémů a rozhodovací dovednosti. Praha: Občanské sdružení Projekt Odyssea. 
Newman, T., \& Blackburn, S. (2002). Transitions in the lives of children and young people: Resilience factors, interchange. Edinburgh: Scottish Executive Education Dept. Retrieved from https://files.eric.ed.gov/fulltext/ED472541.pdf

Paulík, K. (2010). Psychologie lidské odolnosti. Praha: Grada Publishing.

Poledňová, I., Stránská, Z., Vízdalová, H., \& Zobačová, J. (2003). Sociální a kulturní souvislosti výchovy a vzdělávání. Brno: Pedagogická fakulta Masarykovy univerzity v Brně.

Reddy, K. J., Menon, K. R., \& Thattil, A. (2018). Academic stress and its sources among University students. Biomedical and Pharmacology Journal, 11(1), 531-537. https://dx.doi.org/10.13005/bpj/1404

Rejstřík škol a školských zařízení. (2020, May 7). Druh školy/zařízení: C, Střední vzdělávání-školy @ MŠMT. Retrieved from https://rejstriky.msmt.cz/rejskol/

Roorda, D. L., Koomen, H. M. Y., Spilt, J. L., \& Oort, F. J. (2011). The influence of affective teacher student relationships on students' school engagement and achievement: A meta-analytic approach. Review of Educational Research, 81(4), 493-529. https://doi.org/10.3102/0034654311421793

Sacker, A., \& Schoon, I. (2007). Educational resilience in later life: Resources and assets in adolescence and return to education after leaving school at age 16. Social Science Research, 36(3), 873-896. https://doi.org/10.1016/j.ssresearch.2006.06.002

Šolcová, I. (2009). Vývoj resilience v dětství a dospělosti. Praha: Grada.

Statistické ročenky školství, výkonové ukazatele. (2020, May 7). D1.1.1 Vzdělávání ve středních školách - školy, tř́dy, žáci/dívky, nově prijiatí, absolventi - podle druhu vzdělávání @ Ministerstvo školství, mládeže a tělovýchovy - Odbor školské statistiky, analýz a informační strategie. Retrieved from http://toiler.uiv.cz/rocenka/rocenka.asp

Taylor, E., \& Thomas, C. (2001). Resiliency and its implications for schools. Journal of Educational Thought, 36(2), 7-16.Retrieved from https://www.jstor.org/stable/42590260

Ungar, M., Liebenberg, L., Boothroyd, R., Kwong, W. M., Lee, T., Leblanc, J. C., \& Makhnach, A. (2008). The study of youth resilience across cultures: Lessons from a pilot study of measurement development. Research in Human Development, 5(3), 166-180. https://doi.org/10.1080/15427600802274019

Ungar, M., Russell, P., \& Connelly, G. (2014). School-based interventions to enhance the resilience of students. Journal of Educational and Developmental Psychology, 4(1), 66-83. https://doi.org/10.5539/jedp.v4n1p66

Vágnerová, M. (2001). Kognitivní a sociální psychologie žáka základní školy. Praha: Karolinum.

Vašutová, M., \& Panáček, M. (2013). Mezi dětstvím a dospělostí: Vybrané kapitoly z psychologie adolescence. Ostrava: Filozofická fakulta Ostravské univerzity v Ostravě.

Weare, K., \& Nind, M. (2011). Mental health promotion and problem prevention in schools: What does the evidence say? Health Promotion International, 26(S1), i29-i69. https://doi.org/10.1093/heapro/dar075

Wedlichová, I. (2010). Pedagogicko-psychologické př́stupy a strategie v práci se žáky primárního vzdělávání. Ústí nad Labem: Univerzita Jana Evangelisty Purkyně.

Worsley, L. (2006). The resilience doughnut: The secret of strong kids. Eastwood, NSW: Alpha Counselling Services. 


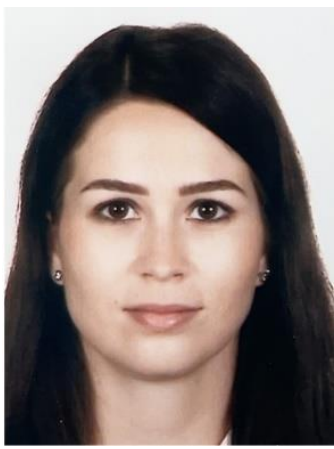

PhDr. Lucie Nečasová obtained her bachelor's and master's degrees in the field of social pedagogy at Tomas Bata University in Zlín. After finishing her master's in 2019, she worked on a rigorous thesis aimed at the resilience of high schools students and preferred coping strategies. The thesis was successfully defended in January 2021, and the present paper introduces the main outcomes of that thesis. Currently, Lucie works at the Department of Social and Legal Protection of Children in a ward office in Kuřim. In addition, Lucie began her Ph.D. studies in 2020, while her main research interest is the issue of socially disabled pupils in a classroom environment. 